\title{
Genetic Disorders of the Exocrine Pancreas
}

An Overview and Update

Editors

Peter Durie, Toronto

Markus M. Lerch, Münster

Albert B. Lowenfels, Valhalla, N.Y.

Patrick Maisonneuve, Milan

Charles D. Ulrich, Cincinnati, Ohio

David C. Whitcomb, Pittsburgh, Pa. 
Updated reprint of Pancreatology (ISSN 1424-3903)

Vol. 1, No. 5, 2001

Publication of this reprint was made possible, in part, by the generous support of

the H.E. Haller Foundation, Pittsburgh, PA, USA

and

Solvay

Pharmaceuticals

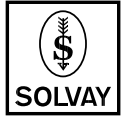

S. Karger

Medical and Scientific Publishers

Basel $\cdot$ Freiburg $\cdot$ Paris $\cdot$ London

New York $\cdot$ New Delhi $\cdot$ Bangkok

Singapore $\cdot$ Tokyo $\cdot$ Sydney
Drug Dosage

The authors and the publisher have exerted every effort to ensure that drug selection and dosage set forth in this text are in accord with current recommendations and practice at the time of publication. However, in view of ongoing research, changes in government regulations, and the constant flow of information relating to drug therapy and drug reactions, the reader is urged to check the package insert for each drug for any change in indications and dosage and for added warnings and precautions. This is particularly important when the recommended agent is a new and/or infrequently employed drug.
All rights reserved

No part of this publication may be translated into other languages, reproduced or utilized in any form or by any means, electronic or mechanical, including photocopying, recording, microcopying, or by any information storage and retrieval system, without permission in writing from the publisher or, in the case of photocopying, direct payment of a specified fee to the Copyright Clearance Center (see 'General Information').

(C) Copyright 2002 by S. Karger AG

P.O. Box, CH-4009 Basel (Switzerland)

Printed in Switzerland on acid-free paper by

Reinhardt Druck, Base

ISBN 3-8055-7411-8

\section{KARGER}

Fax + 41613061234

E-Mail karger@karger.ch

www.karger.com 


\section{Contents}

Foreword

1 Genetic Disorders of the Exocrine Pancreas

Neoptolemos, J.P. (Liverpool)

Consensus Conference

2 Genetic Testing for Hereditary Pancreatitis: Guidelines for Indications, Counselling, Consent and Privacy Issues

Ellis, I. (Liverpool); Lerch, M.M. (Münster); Whitcomb, D.C. (Pittsburgh, Pa.)

13 Pancreatic Cancer in Hereditary Pancreatitis: Consensus Guidelines for Prevention, Screening and Treatment

Ulrich, C.D. (Cincinnati, Ohio)

Hereditary Pancreatitis

20 Systemic Overview of Genetic Variants of Cationic Trypsinogen and SPINK 1 in Pancreatitis Patients

Teich, N.; Mössner, J.; Keim, V. (Leipzig)

23 Gene Mutations in Children with Chronic Pancreatitis

Witt, H. (Berlin)

30 Hereditary Pancreatitis in North America: The Pittsburgh-Midwest Multi-Center Pancreatic Study Group Study

Applebaum-Shapiro, S.E.; Finch, R.; Pfützer, R.H.; Hepp, L.A. (Pittsburgh, Pa.); Gates, L. (Lexington, Ky.); Amann, S. (Tupelo, Miss.); Martin, S.; Ulrich, C.D., II (Cincinnati, Ohio); Whitcomb, D.C. (Pittsburgh, Pa.)

35 Hereditary Pancreatitis in Japan: A Review of Pancreatitis-Associated Gene Mutations

Nishimori, I.; Onishi, S. (Kochi)

39 Acute and Chronic Pancreatitis in Patients with Inborn Errors of Metabolism

Simon, P.; Weiss, F.U.; Zimmer, K.-P.; Koch, H.G.; Lerch, M.M. (Münster)

48 SPINK1 Mutations Are Associated with Multiple Phenotypes

Pfützer, R.H. (Mannheim); Whitcomb, D.C. (Pittsburgh, Pa.)

52 The Pathobiochemistry of Hereditary Pancreatitis: Studies on Recombinant Human Cationic Trypsinogen

Sahin-Tóth, M. (Los Angeles, Calif.) 
Pancreatic Cancer

57 Hereditary Pancreatic Cancer

Lynch, H.T.; Brand, R.E.; Deters, C.A.; Shaw, T.G.; Lynch, J.F. (Omaha, Nebr.)

63 Gene-Environment Interactions in Pancreatic Cancer

Malats, N. (Barcelona)

68 Inherited Pancreatic Cancer: Surveillance and Treatment Strategies for Affected Families

Rulyak, S.J.; Brentnall, T.A. (Seattle, Wash.)

77 Molecular Diagnosis of Early Pancreatic Ductal Adenocarcinoma in High-Risk Patients

Wong, T.; Howes, N.; Threadgold, J.; Smart, H.L.; Lombard, M.G.; Gilmore, I.; Sutton, R.; Greenhalf, W.; Ellis, I.; Neoptolemos, J.P. (Liverpool)

101 Update of Familial Pancreatic Cancer in Germany

Bartsch, D.K.; Sina-Frey, M.; Ziegler, A. (Marburg); Hahn, S.A. (Bochum); Przypadlo, E.; Kress, R.; Gerdes, B.; Rieder, H. (Marburg)

108 Pancreatic Cancer: Factors Regulating Tumor Development, Maintenance and Metastasis

Shi, X.; Friess, H.; Kleeff, J.; Ozawa, F.; Büchler, M.W. (Bern)

116 Timing and Extent of Surgical Intervention in Patients from Hereditary Pancreatic Cancer Kindreds

Kekis, P.B.; Friess, H.; Kleeff, J.; Büchler, M.W. (Bern)

Cystic Fibrosis and Shwachman-Diamond Syndrome

122 Neonatal Screening for Cystic Fibrosis: Long-Term Clinical Balance Mastella, G.; Zanolla, L.; Castellani, C.; Altieri, S. (Verona); Furnari, M. (Palermo); Giglio, L. (Trieste); Lombardo, M. (Messina); Miano, A. (Cesena); Sciuto, C. (Catania); Pardo, F. (Palermo); Magazzù, G. (Messina)

129 CFTR and Cationic Trypsinogen Mutations in Idiopathic Pancreatitis and Neonatal Hypertrypsinemia

Gomez Lira, M.; Patuzzo, C.; Castellani, C.; Bovo, P.; Cavallini, G.; Mastella, G.; Pignatti, P.F. (Verona)

134 Shwachman-Diamond Syndrome: Clinical Phenotypes

Cipolli, M. (Verona)

Conference Report

140 Third International Symposium on Inherited Diseases of the Pancreas

Whitcomb, D.C. (Pittsburgh, Pa.); Ulrich, C.D. (Cincinnati, Ohio); Lerch, M.M. (Münster); Durie, P. (Toronto); Neoptolemos, J.P. (Liverpool); Maisonneuve, P. (Milan); Lowenfels, A.B. (Valhalla, N.Y.)

149 Lifetime Achievement Award Henry T. Lynch, MD International Symposium on Inherited Diseases of the Pancreas DiMagno, E.P. (Rochester, Minn.)

154 Author Index

155 Subject Index 